\title{
Trauma of Displacement in V.S. Naipaul's The Mimic Men
}

\author{
Masoumeh Mehni ${ }^{1}$, Noritah Omar $^{1} \&$ Ida Baizura Binti Bahar ${ }^{1}$ \\ ${ }^{1}$ Faculty of Modern Languages and Communication, University Putra Malaysia, Malaysia \\ Correspondence: Masoumeh Mehni, Faculty of Modern Languages and Communication, University Putra \\ Malaysia, Malaysia. E-mail:sumimehni@yahoo.com
}

Received: April 8, 2015 Accepted: May 29, 2015 Online Published: August 18, 2015

doi:10.5539/ass.v11n24p95 URL: http://dx.doi.org/10.5539/ass.v11n24p95

\begin{abstract}
This research considers displacement in Naipaul's The Mimic Men as a traumatic experience. Taking an interdisciplinary approach to the subject of my study, it explores the historical and psychological dimensions of the displacement in the novel, as well as its literary representations. In the first step, I depicted the displacement as a traumatic experience for the protagonist by the illness which displacement causes Post Traumatic Stress Disorder. In the second step, I suggested two ways the protagonist goes through to remember their trauma. These ways are two different kinds of memory, namely, "acting out" and "working through". I take "acting out" and "working through" as different but not opposite processes. "Acting out" and "working through" may never be totally separated from each other, and the two may always mark or be implicated in each other. In the third step, I also looked at the impacts of trauma of displacement on the structural and formal components of The Mimic Men.
\end{abstract}

Keywords: Trauma, Displacement, PTSD, “Acting out”, "Working through”, Trauma and Literature

\section{Introduction}

V.S. Naipaul is an Indian by ancestry, a Trinidadian by nativity and British by residence and intellectual training. The distinctive combination of circumstances, which relates him to the three societies, certainly plays a predominant part in shaping his sensibility and determining his writing career. He said, "when I speak about being an exile or a refugee, I am not just using a metaphor" (Rowe-Evans 62). He was born into exile, separated his racial and cultural roots and driven into another exile from the land of his birth. The contradictions inherent in his background form the pivot of his work. As Landeg White says, “... the struggle against the effects of displacement lies at the heart of his work" (3).

V.S. Naipaul is obsessed with displacements in his works. Portrayal of displacement is his works is unique. In Gillian Dooley's words in her article, "The Imaginative Promptings of My Many-Sided Background V.S. Naipaul's Diasporic Sensibility", Naipaul "instead of drawing heavily on memories of the homeland and the collective identity, he has made his difference into a distinction and turned his alienation into an abiding preoccupation"(3) .

Leading trauma scholar, Cathy Caruth, in her book Trauma: Exploration in Memory (1995), asserts, "To be traumatized is precisely to be possessed by an image or event" (4). Naipaul's obsession by displacement in his works implies that displacement is a traumatic experience for him, and as a traumatic event overwhelms the psychic defences and normal processes of registering memory traces, displacement should be approached in his works psychologically, an issue which has been relatively ignored by his critics. The main focus of Naipaul's critics has been on postcolonial diasporic studies which consisted political and/or ideological aspects of displacement This research considers displacement in Naipaul's The Mimic Men as a traumatic experience. Taking an interdisciplinary approach to the subject of my study, it explores the historical and psychological dimensions of the displacement experience, as well as its literary representations. Based on the theoretical work of trauma theorists such as Cathy Caruth, Dominick LaCapra, this study attempts to investigate the effects of trauma of displacement in The Mimic Men.

\section{The Mimic Men}

The Mimic Men is the story of Ranjit Kripalsingh or Ralph Ranjit Kripalsingh, as he is prefer to be known, the only son of a Hindu family on the fictional Caribbean island of Isabella who moved to England to continue his studies. He married an English girl named Sandra and returned to Isabella, where he became a successful 
property developer and building contractor, and entered into politics. His marriage broke up and after his sudden withdrawal from his political career in Isabella, he went back to England and settled down in the old boarding house (now a hotel) where he started writing his memoirs.

\section{Theoretical Framework}

In 1980, the arrival of Post-Traumatic Stress Disorder (PTSD) assisted to consolidate a trauma paradigm. The American Psychiatric Association included in the new edition of its official diagnostic manual the symptom indicators for a new illness: Post-Traumatic Stress Disorder. Individuals who experience traumatic events seem to produce certain identifiable somatic and psycho-somatic disturbances. Aside from myriad physical symptoms, trauma disrupts memory, and therefore, identity in peculiar ways. The American Psychiatric Association official diagnostic manual classifies the PTSD's symptoms: The first cluster of symptoms relate to the ways in which the traumatic event is persistently 're-experienced' - through intrusive flashbacks, recurring dreams, or later situations that repeat or echo the original. Weirdly, the second set of symptoms suggests a complete opposite: 'persistent avoidance of stimuli associated with the trauma' that can range from avoidance of thoughts or feelings related to the event to a general sense of emotional numbing to the total absence of recall of the significant event. A third set of symptoms points to the 'increased arousal, including loss of temper control, hyper-vigilance or exaggerated startle response'. Symptoms can come on acutely, persist chronically, or in another strange effect, appear belatedly months or years after the precipitating event.

There are two very broad ways of coming to terms with trauma: "acting out" and "working through". Dominick LaCapra defines "acting out" as a state "in which one is haunted or possessed by the past and performatively caught up in the compulsive repetition of traumatic scenes [...]. In "acting out", tenses implode and it is as if one were back there in the past reliving the traumatic scene" (Writing History 21). There are many different ways in which a person can "act out" his or her traumatic experiences. In acting out, one usually keeps on repeating the painful events in the forms of flashbacks, nightmares or compulsive behaviour, dreams, hallucinations, illusions, avoidance of problem, lack of memory, and excess of memory. In The Mimic Men, Singh mostly "acts out" his trauma of displacement through dreams, images, his behaviour and reactions in different situations and his confrontation with people. "Working through" is the other possible reaction to trauma. Dominick Lacapra in his book, Writing History, Writing Trauma (2001), states that "In the working through, the person tries to gain critical distance on a problem, to be able to distinguish between past, present and future" (143). Generating countervailing forces to "acting-out" is the way that a traumatised can palliate the symptoms of trauma. Besides generating countervailing forces to "acting-out", LaCapra seconds the psychoanalytic requisite of testimony as the fundamental stipulation to working through trauma. In the following section, I elaborate how Singh "works through" his trauma.

One of the other concepts I used for the analysis of The Mimic Men is the impact of trauma theory on literary texts. For an analysis of literature on the basis of the trauma theory, it is important to go beyond the psychological analysis and to consider the structural and formal components of the work of art. In trauma fiction, conventional narrative techniques do not suffice to represent the traumatic event. Instead, trauma fiction pushes these conventional techniques to the limit. Anne Whitehead sums up some of the main characteristics of trauma fiction in her eponymous book, 'Trauma Fiction' (2004). Non-linearity, repetition and intertextuality form three important modes of representation in the traumatic narratives in Whitehead's book, all of which are traced in The Mimic Men.

\section{Post-Traumatic Stress Disorder}

This study considers displacement as a traumatic experience for the protagonist in Naipaul's The Mimic Men by the illness that displacement causes, PTSD (Post Traumatic Stress Disorder). In The Mimic Men, there are some of these symptoms which I depict in the following parts. The Mimic Men's protagonist Ralph Singh shows symptoms of PTSD both in Isabella and England. Although Ralph Singh's ancestors emigrated from India to Caribbean many years ago and he was born in the Caribbean island of Isabella, he feels displaced there. As a child, Singh does not have a sense of belongingness in Isabella. He describes his childhood like this:

I could scarcely wait for my childhood to be over and done with. I have no especial hardship or deprivation to record. But childhood was for me a period of incompetence, bewilderment, solitude and shameful fantasies. It was a period of burdensome secrets. (90)

For him, it is this sense of displacement that makes him a nonentity. Thus, shortly after his failure as a cricketer, he decided to leave Isabella, "I wished to make a fresh, clean start. And it was now that I resolved to abandon the shipwrecked island and all on it..." (p. 118). He resolves to seek his autonomous identity in London, the bosom of the mother: 
Coming to London, the great city, seeking order, seeking the flowering, the extension of myself that ought to have come in a city of such miraculous light, I had tried to hasten a process which had seemed elusive. I had tried to give myself a personality (p. 26)

Thus, as an immigrant student in London living among a group of displaced people on the fringe of London's reality, wanting hopelessly to make contact with the city, but being unable to do so. Singh likens the reality of the city (which he yearns for) to a malicious living organism that feeds on the personalities it divides:

In the great city, so three-dimensional, so rooted in its soil, drawing colour from such depths, only the city was real. Those of us who came to it lost some of our solidity; we were trapped into fixed, flat postures. And in this growing disassociation between ourselves and the city in which we walked, scores of separate meetings, not linked even by ourselves, who became nothing more than perceivers: everyone reduced, reciprocally, to a succession of such meetings, so that first experience and then the personality divided bewilderingly into compartments (p. 27)

Regarding the above quotation, Singh is unable to accomplish his dream of finding his autonomous identity in his ideal landscape, London, and thus overcomes his sense of displacement. On the contrary, he starts to have "the panic of ceasing to feel myself as a whole person" (27). After his unhappy experience in London, Singh returns home to Isabella, where he is offered a second chance to declare his autonomy.

Judith Herman in her book, Trauma and Recovery (1997) writes,

Traumatic events call into question basic human relationships. They breach the attachments of family, friendship, love and community. They shatter the construction of the self that is formed and sustained in relation to others. They undermine the belief systems that give meaning to human experience. They violate the victim's faith in a natural or divine order and cast the victim into a state of existential crisis. (50)

Singh's relationships illustrate the exile's isolation, his split or fragmented identity. He is incapable of forming meaningful or lasting relationships. He describes his distaste for intimacy yet his fetish for fondling and being fondled: "Intimacy: the word holds the horror. I could have stayed for ever at a woman's breasts, if they were full and had a hint of weight that required support. . . [As for sex] I was capable of the act required, but frequently it was in the way that I was capable of getting drunk or eating two dinners" (25). For Singh, breasts signify the centre, home, the time before the shipwreck of his exile's life. He is initially attracted to his future wife, Sandra, because her breasts seem to match this ideal. In a dream he imagines himself a baby suckling at his mother's breast. "What joy!" he exclaims. "The breast on my cheek and mouth: a consoling weight, the closeness of soft, smooth flesh" (116). His confessions of sexual failures are similar to his inability to be part of or to lose himself in someone or some group beyond himself.

Regarding existentialism in Naipaul's works, Serafin Roldan-Santiago in her article "Pessimism and Existentialism in V. S. Naipaul" states that, "existential sense is thus the idea or driving force that envelops many of his narratives". In The Mimic Men, there is an existential vision of an absurd, meaningless universe, a world populated by mankind without any god or purpose. Singh's fear of death, reinforced by the drowning he witnesses at the beach, his sense of futility, his feeling that only what is seen exists, and that 'A man was only what he saw of himself in others' (p. 100) are familiar themes from Sartrean existentialist philosophy. In addition, existentialist is Singh's desire to be part of something larger, his concern with how he appears to others, and his attempt to transcend personal solitude through political action. Such existentialist, Sartrean, themes are introduced early in the novel: 'It was up to me to choose my character' (p. 20); 'We become what we see of ourselves in the eyes of others' (p. 20). He is not certain whether his character has been created by others or whether it is 'one and indivisible'. In the next part, I discuss how Singh responds to the trauma of displacement and sees if he "acts out" or "works through" his trauma of displacement.

\section{Acting Out}

So far, I have explored how displacement is traumatic for the protagonist of The Mimic Men. In the following, I investigated the ways Singh responds to his trauma. There are two very broad ways of coming to terms with trauma: "acting out" and "working through".

In childhood, Singh responds to his sense of displacement by dreaming of India, the homeland, and of his origin. He reads books on Asiatic and Persian Aryans and dreams of horsemen who look for their leader:

China was the subject of Hok's secret reading. Mine was of Rajputs and Aryans, stories of knights, horsemen and wanderers. I had even read Tod's difficult volumes. I had read of the homeland of the Asiatic and Persian Aryans, which some put as far away as the North Pole..And I would dream that all over the 
Central Asian plains the horsemen looked for their leader. (98)

Singh is also troubled by his Indianness in the New World. Although he dreams of an idealised Indian past to which he will return, he attempts to Anglicize himself, "My reaction to my incompetence and inadequacy had been not to simplify but to complicate. For instance, I gave myself a new name" (93). Singh's idealism about a heroic past totally collapses by the actions of his father. Although Singh spends time more with his mother's family, he has tendency towards his father, "I must explain. I cherished my mother's family and their Bella Bella Bottling Works. But in my secret life I was the son of my father, and a Singh" (98). Singh's family life is disrupted when his father goes away to choosing a life of 'sanyasi' living with another woman. His father wants to use religion as a tool to secure a place of power for himself and to retain Hinduism; in the process, he destroys his son's belief. Singh was further shocked when his father sacrificed Tamango, the race horse, which according to the Hindu religion is an act of sacrifice to secure prosperity and fertility. Although Singh idealises his Hindu past and culture, he is in fact unable to understand Hinduism, and thus, as Thieme has observed, when the horse is killed, the ideal past collapses and the concrete experience shocks the child (133). Hindu rituals have lost their meaning in Isabella as the people have lost their connection with India, its culture, customs and traditions. Thus, as Bruce King claims, by leaving India and going to the Caribbean islands, the Indians are doomed to isolation and dislocation:

The process of losing one's Indianness started with leaving India. That was the original sin, the fall. After that Indian traditions could only either decay into deadening ritual or become diluted, degraded and eventually lost through outside influences and intermarriage with others. (68)

Singh's heroic thoughts about India crumbled and his own culture became meaningless to him. Singh understood that an island so full of viciousness could not be an epitome for anyone to search for history or have a productive future. Thus, his suffocation grew and his urge to escape became even stronger: "I wished to fly, to begin afresh, lucidly." (169-170)

Singh creates an ideal and heroic past which is in conflict with the real-life condition in Isabella. For example, he goes to the beach house owned by his grandfather and one day, he sees the death of three children who are drowned in the sea while the fishermen do nothing to save them (108-109). At that point, he realizes that Isabella cannot be the ideal landscape he is searching for. As Thieme has observed, the beach scene refers to the myth of Perseus who was saved from being drowned in the sea by Dictys, a fisherman and a hero, who presents a contrast with the passive and selfish Carib-African fishermen. Hence, "Singh's experience on the beach makes him too aware of the distance between Isabella and his true, pure world" (117). After seeing the drowning, he concentrates on school and takes up sports. He puts his name down for cricket but after preparing for some time, he decides on the day of competition to withdraw. While writing his biography, he recalls the dream that has caused him to withdraw:

I had dreamt that I was a baby again and at my mother's breast. What joy! The breast on my cheek and mouth: a consoling weight, the closeness of soft, smooth flesh. It had been at dusk, in a vague setting, no lights in a back veranda, all around a blue of dark bush. My mother rocked and I had the freedom of her breast. A dream? But no, I was not dreaming. What pain then, what shame, to awaken! (116)

To Singh, what prevents him from declaring his autonomy at school is his sense of not belonging to the "shipwrecked island" (105) of Isabella; for him, it is this sense of displacement that makes him a nonentity. Thus, shortly after his failure as a cricketer, he decides to leave Isabella, "I wished to make a fresh, clean start. And it was now that I resolved to abandon the shipwrecked island and all on it..." (118). His eventual departure for London is preceded by the drama and intensity of his incestuous affair with Sally and near-showdown with Dalip (190).

Singh travels to London in order to find sense of belonging as he found Isabella as a place associated with the sense of unbelongingness. In London, Singh locates an initial sense of ordering and calmness. He speaks of the city as "so solid ..." as it presents a solidity and simpleness, a place easily understood, presenting a kind of order not available in Isabella (23). Singh's boarding house and the relationship with Lieni further this initial sense of order, providing Ralph with guidance through the city. This order is quickly lost, however, as Ralph notes, "so quickly had London gone sour on me" (22). His loss of order is marked by the breakup of the boarding house, "with Lieni and Mr Shylock's boarding-house one type of order had gone for good. And when order goes it goes" (36). Singh comments that he can no longer "feel [himself] as a whole person," that he has "become distorted," and that "those of us who came to [London] lost some of our solidity" (33-32). London draws Singh through the growing confusion that constantly pulls him apart and brings about a rootlessness and impermanence to his self. It is because of this that Singh describes London as "the greater disorder, the greater shipwreck" and he predicts, 
"the crash was coming", which would bring about the culmination of the messiness of this London experience $(214,33)$. Singh explains concerning his first stay in London, "it was during the time of breakdown and mental distress when ... I travelled about England and the Continent with no purpose, not even pleasure" (49).

When the boarding house breaks up, Ralph enters a life of transience, "From room to room I moved, from district to district going ever farther out of the heart of the city" (36). He describes himself as "restless" and having "this feeling of being adrift ...," of having been destabilised, of having the (once) solid ground pulled out from beneath his feet $(36,32)$. Ralph attempts to deal with these feelings through movement. As Robert Hamner recognises in his study on Naipaul, "... Ralph tries to locate himself and give concreteness to his actions by touring London ... and by pursuing affairs with various seemingly anonymous women" (139). This movement is initially observable in his visits to the art galleries, which he utilises because of "their excuse for movement backwards, forwards, and sideways, any number of times ..." (26-7). Ralph's movement grows in intensity with the excursion trains, which allow him to move across England to pick up women. This movement becomes so intense, "Will I be believed if I say that on four successive Wednesdays I made lucky strikes on the Oxford train?" (27)

Dominick LaCapra in his book, Wring History, Writing Trauma (2001), writes, “As in acting out in general, one possessed $[\ldots]$ by the past and reliving its traumatic scenes may be tragically incapable of acting responsibly or behaving in an ethical manner" (28). In The Mimic Men, the unethical behaviour manifests in Singh's sexual promiscuity. He keeps a diary that he says developed into "a type of sexual autoeroticism",

Nor can I understand why I began keeping a sexual diary. I began it, I remember, out of boredom and idleness; but soon it developed into a type of auto-erotic enterprise. It was myself, my minutest reactions that I sought to analyse. (25-26)

One of the other Singh's characteristics which depicts his "acting out" is his behaviour with women. Singh's encounter with women mostly ended in violence, an extraction of his anguish "this remained a shame for some time; for I had actually shouted at the girl. I have been guilty of three or four acts of pure cruelty in my life" (32). Singh knew his personal agony was no excuse for the bizarreness he showed towards these women but he retained some perverse behaviours:

"I took to retaining trophies from the girls who came to the book-shaped room: stockings, various small garments, once even a pair of shoes from a girl who had thought of staying the night. Though even now I cannot understand my motives. Nor can I understand why I began keeping a sexual diary. I began it, I remember, out of boredom and idleness; but soon it developed into a type of auto-erotic enterprise" (30-31).

Singh took certain pleasure in rejecting the woman who came across his life, "I said to a French woman, 'Do you dance?' She at once rose. It was then that out of nowhere the impulse of cruelty came to me. I said, 'I don't.' And I left" (20). It was in London during his period of education that he met Sandra, who was to be his wife later. Singh discovered "though of the city, her position in it was like my own. She had no community, no group, and had rejected her family" (53). Sandra was more a confidante for Singh and he was in need of her protection:

"I had such confidence in her rapaciousness, such confidence in her as someone who could come to no harm- a superstitious reliance on her, which was part of the strength I drew from her-that in the moment it seemed to me that to attach myself to her was to acquire that protection which she offered, to share some of her quality of being marked, a quality which ones was mine but which I had lost" (56).

It never occurred to Singh to ask her for marriage with love, "why don't you propose, you fool?" (46). It is clear that Singh felt his position elevated and secured in the presence of Sandra:

"....it was in her walk, in the bite of her speech, even in the way she ate food which she considered expensive.

But how could I resist her quick delight? Her very rapaciousness attracted me. To me, drifting about the big city that had reduced me to futility, she was all that was positive. Her delight strengthened me" (54).

Singh remembers his marriage as an "absurd ceremony" (58). In fact, what Singh felt towards her was lust not love. Singh 's marriage does little to order the situation, as immediately following the ceremony, he experiences a panic and loss of control and flees to a public house to drink (. 59). At hearing the news of his murdered father, Singh resorts to movement and sex, "I walked about the streets. Later I went with a prostitute" (215). Following this final chaotic movement about London, Singh simply declares, "I was ready to leave" (215). At this point, his frenzied the movements and breakdown of the self have reached their pinnacle, propelling him from London to Isabella.

Singh never found the order he was searching for in London, rather he found himself into greater disorder. He says "we talk of escaping to the simple life. But we do not mean what we say. It is from simplification such as 
this that we wish to escape, to return to a more elemental complexity" (43). Upon arrival to Isabella, Singh experiences a calmness and a resettling of the chaos and frenzy of London, describing the island as "a scene of peace ..." (62). Back in Isabella, Ralph regains a solidity and order to his self. He is even able to successfully repress some initially negative reactions to his return, "this return so soon to a landscape which I thought I had put out of my life for good was a failure and a humiliation. Yet this, together with all my unease, I buried away" (60). This, however, is a short-lived calm that quickly passes over to the chaos. The cause for Isabella's lack of order is the same as the cause for Ralph's initial departure from Isabella, as the island is a place that causes Ralph to "[panic] at not being able to tear down the unreality about him to get at the hard, the concrete, where everything becomes, simple and ordinary and easy to seize" - a panic caused by his inability to grasp a solidity or order while on the island (86).

In Isabella, Singh and Sandra join a social group, the elitist set of Isabella. Even the social group, initially noted as offering a sense of order, is almost simultaneously described as "a haphazard, disordered and mixed society ... [a] fluid group" (66). Peter Nazareth in, "The Mimic Men' as a Study of Corruption", comments on the instability of this social group, "And the 'jet set' Singh joins after his return from England is just so much more jetsam-false, unreal, living an artificial life ...", so that Ralph's attempts at a pure and ordered life are almost immediately thwarted by his association with a "mixed," "disordered," and aimlessly floating ("jetsam") social group (143).

In a further attempt to instil order, Singh builds the Roman house, "I was struck by the simplicity of the Roman house, its outward austerity, its inner, private magnificence ..." (84). The house offers simplicity and, through its distinctions between public ("outward") and private ("inner"), an imposed distinction and ordering. These attempts, however, fail, as Ralph never does regain order, calm, or simplicity on Isabella. The destruction of Ralph's house during his housewarming party clearly marks this inability to achieve order.

As Singh's marriage disintegrates, he desperately attempts to regain his order. He, once again, resorts to an aimless sort of movement, in his attempts to regain control, "At nights [Sandra and I] would go out driving, just for the sake of motion. We drove to the airport and sat drinking in the lounge with in transit passengers, listening to the names of foreign cities" (83). Not only do they move, but they go to a site of movement and talk to the people who are on the move. Singh and Sandra shared not love but distress together and thus Singh feels "we were compatible, yet it was this very compatibility that drew her away from me" (81). The loveless marriage grew apart, dishonesty to dishonesty, unease to unease, "we had taken to sleeping in separate rooms so that the sleeplessness of the one might not disturb the other" till Singh felt disgusted towards her, "and subtly my attitude towards her changed: "The very things I had once admired in her-confidence, ambition, rightness-were what I now pitied her for..." (69). Now I was truly appalled. I wished to get away at once, to reflect, to be alone again" (58). Singh did not try to stop Sandra when she went away. Moreover, Singh knew:

"Sandra was after all in a position to leave: other relationships awaited her, other countries. I had nowhere to go; I wished to experience no new landscapes; I had cut myself off from that avidity which I still attributed to her. It was not for me to decide to leave; that decision was hers alone" (91)

His broken marriage had left him more confused and with a sense of utter failure. After the failure of his marriage, Singh decided to become a politician in order to fulfil his psychological need for order and an identity. "Only with The Mimic Men does the recognition of a national history in the landscape become necessary condition for establishing a stable identity" (Cooke 32). He also took up politics because he wanted to get a real view of himself, to rid himself of the "panic of ceasing to feel myself as a whole person" (33). His reasons behind joining politics were not to help his fellow Islanders but to satisfy his own ego and to feel himself in a position of power. As a politician, Singh does not concentrate on helping to reduce poverty or the sufferings of the people but he is obsessed with 'naming' everything. That showed his thirst for power and ownership, "So I went on naming; and later, I required everything-every government building, every road, every agricultural scheme - to be labelled. It reinforced that sense of ownership which overcame me..." (215). At the moment of supreme achievement in politics, Singh reverts to images of childhood to express his hopelessness, "The play was over. Exhilaration went. We could no longer draw strength from one another. It was one of those occasions when each person looks into himself and finds only weakness, sees the boy or child he was and has never ceased to be" (199-200).

Singh referred to his political activity as 'drama'. 'Drama' because all his actions as a politician were only a series of experiments that he applied on the Island and the people, to satisfy his ego. It was not a real-life experience for him and he was aware that his role as a 'colonial' politician was meaningless, it was more of a sarcasm. Singh writes: 
"Politicians are people who truly make something out of nothing. They have few concrete gifts to offer. They are not engineers or artists or makers. They are manipulators; they offer themselves as manipulators. Having no gifts to offer, they seldom know what they seek. They might say they seek power. But their definition of power is vague and unreliable" (43).

Singh realised that his sense of 'drama' and his pretensions did not bring any peace to the Island and the people suffered from social and economic unrest. Under such conditions, the only solution they had to stabilise the condition of the Island was the nationalisation of the sugar estate, owned by an upper-class English man, Lord Stockwell. When Singh went to persuade the Englishman, he failed and was moreover humiliated by the English ministers. They refused to take the matter seriously and treated Singh like a child. Singh, not a member of the imperial power, was made to feel his status as a politician as inferior and of a failure. Singh knew without the help from the English, he could not take any solution back to his country, thus he asked, "How can I take this message back to my people?" and Stockwell indicated clearly that he had other things to do than assisting the public relations of the colonial politician, "you can take back to your people any message you like" (224) and that was the end. The disorder and instability of Ralph's political movement, apparent almost from its inception, carry this intensity and chaos to even greater extremes. Ralph describes the situation "of the political group as characterized by feelings of "frenzy", "unease", "anarchy" "hysteria", "precariousness", "panic", and "drifting" $(239,246,252,263)$. This is the upheaval destruction of order and calm, and all-up-in-the-air quality of Ralph's life on the island that constantly refuses any attempts at settlement. His visit to London for negotiations presents an even greater movement than he previously exhibited. While in London, he moves around the city and has an affair with Stella, the action that he describes as possessing a sort of "Frenzy" $(267,275)$. This frenzy further increases during his stopover, which allows him to move through a new city, so transient and un-rooted, "as in a dream," that he describes, "my disturbance was [now] complete" (279). By this point, Ralph's self becomes disordered, chaotic, un-rooted, unstable, et cetera, to a whole new extreme. He eventually returns to Isabella, though he recognises that "there was no need for me to return ...," as the middle stage has reached such frenzy that he can no longer remain on Isabella, but must continue his movement toward the completion of his form (278). By this point, the unease feelings that Ralph initially suppress upon his arrival to Isabella have fully resurfaced, as he once again I climax, jettisoning him away from Isabella to the conclusion of the form in London, feels himself a foreigner on the island (248). Ralph's frenzy and movement eventually climax, jettisoning him away from Isabella to the conclusion of the form in London.

After his failure in politics, Singh's return to London experiences a brief period of intense movement and homelessness while searching for a place to live beyond London's city limits. During this period, Ralph moves from train station to another train station with no home at all except the movement of the trains, leading a "gypsy life" (299). Finally, he finds a room in a hotel in the suburbs of London. His hotel room is prison-like and characterless with its "regulation hotel furniture" (34). It is tawdry, "Nothing here has been fashioned with love or even skill; there is as a result nothing on which the eye rests with pleasure" (33). As nondescript and limiting as the hotel room is, though, Singh prefers it to the city beyond, "It is a relief to get back from this to the hotel. Here at least there is decorum and calm; no one insists on an impossible communication" (34), an escape from the perceived vulgarity and rabble of the metropolis. Singh the exile, the alienated man, observes of the Londoners and London beyond his hotel room:

"I do not believe that there is communication between these people any more than I believe in the hilarity of the advertisements by which they are surrounded: those irritating drawings in which the mouths of funny men are too wide open . . . those beer-mats whose circular legends I know by heart. Who comes here? A Grenadier. What does he want? A pot of beer" (35).

He also acts out his trauma of displacement in London by dreaming:

I dreamt that in this city I was being carried helplessly down a swiftly flowing river, the Thames, that sloped, and could only break my fall by guiding my feet to the concrete pillars of the bridge that suddenly spanned the river, and in my dream I felt the impact and knew that I had broken my legs and lost their use forever - but as in a dream, I say, the terrors of arithmetic disappear. (91)

As depicted, displacement was a traumatic experience for Ralph Singh and he first responded to it by "acting out" his trauma of displacement. In the following section, I elaborate how Singh "works through" his trauma. LaCapra sees "working through" of a traumatic experience as a process which starts with "acting-out".

\section{Working Through}

"Working through" is the other possible reaction to trauma. Dori Laub writes in the arduous process of working through, "survivors beginning to remember often desire to be alone, although very much in someone's presence" 
(71). Singh, in his subsequent exile back in England at the age of forty, lives in a room in a suburban residential hotel, and avoids contact with any of his former friends, lovers, and acquaintances. Once settled in the hotel, Ralph obtains simplicity and calmness. The way of life provided by the hotel plays a significant role in this ability to obtain order, as Singh comments on, "the constriction and order of hotel life .... Order, sequence, regularity ..." (293). Through this order of the hotel, Singh develops a routine and sense of order in his life, commenting that he and the other tenants "have simplified our lives" $(294,296)$. In addition to the order of the hotel, Singh obtains order through his writing.

Emphasis is also frequently put on the act of testimony as being part of the "working through" process. Singh starts writing two times; first, when he is a politician .However, Singh falls in the fantasy of his retirement state. He cherishes a vision of a quiet life on an old cocoa-estate. He understands now, as he writes about it, that "it was yearning, from the peak of power, for withdrawal; it was wistful desire to undo" (43). Singh starts writing for the second time when he is living in the hotel room in London:

I thought when I began this book that it would be the labour of three or four weeks. Memories of my fluency, on The Socialist, in cabinet, were still fresh; the five thousand- word paper on the reorganization of the police, not a negligible document, had been the concentrated work of an evening. After eighteen months of the anaesthetizing order of life in this hotel, despair and emptiness had burnt themselves out. And it was with a delicious sense of anxiety and of being employed again that I got the hotel to give me a writing-table, set it beside the window, and composed myself to work. (242)

Thus, the act of writing, which at first is perceived by the narrator as a "substitute for what it then pleased me to call life" (244), becomes the instrument through which Singh begins "to impose order on [his] own history, [and] to abolish that disturbance [within him]" (243). As he says, "it never occurred to me that the writing of this book might have become an end in itself, that the recording of a life might become an extension of that life" (244). As he writes the book, a process of creation begins to take place, "one order, of which I form part, answering the other, which I create" (245). Eventually, the very act of writing, despite "its initial distortion, clarifies, and even becomes a process of life" (251). In other words, a process designed to organise and give meaning to life becomes life itself and thus, the basis which charts Singh's and his society's development:

And this became my aim: from the central fact of this setting, my presence in this city which I have known as student, politician and now as refugee-immigrant, to impose order on my own history, to abolish that disturbance which is what a narrative in sequence might have led me to. (243)

Writing his memoirs also makes his messy past in Isabella manageable, "sealing off such experience and activity" so as not to disturb the resolution of the form's conclusion (12). As a result, Singh explains, "... the conviction was strong that I was again in a well-organized country" (297).

One of the important features of Naipaul writing that repeated in The Mimic Men is the ambivalences that the protagonist shows toward Trinidad and England that demonstrates the implication of "acting out" and "working through" in the novel. Before his departure from the colony for the English metropolis, Singh infuses the world beyond the tiny island with a specialness. He is particularly fascinated by the thought of snow, "on the snow slopes of the Laurentians [in Canada], was the true, pure world" (146). His romantic, quasi-religious images of the metropolis and the world beyond Isabella assure his disappointment and eventual disillusionment on his arrival there. His memoirs convey that surprise and disillusionment; he is particularly struck, for example, by the difference between the glamorous, regal image of the BBC imparted to international listeners and the plainness of its operations and facilities:

"there in the canteen of a radio service which, when picked up in remote countries, was the very voice of metropolitan authority and romance, bringing to mind images, from the cinema and magazines, of canyons of concrete, brick and glass, motorcars in streams, lines of lights, busyness, crowded theatre foyers, the world where everything was possible; there now, at the heart of that metropolis, we sat, at a plastic-topped table, before thick cups of cooling tea and plates with yellow crumbs" (46).

In its inner sanctum, the BBC, the voice of metropolis and empire, loses its quasi-magical quality and becomes ordinary; like the radio station, the metropolis quickly loses its aura as well. The "gold of the imagination" always turns into the "lead of the reality," Singh laments. Incorporated into the routine of the metropolis, he loses any special feeling about where he is or what he is doing. In exile, with an identity divided between colony and metropolis, Singh, just as he has idealised the "real world" beyond Isabella, constructs a counterweight romance of the island world he has left behind. He falls into a reverie of his retirement on a cocoa plantation in Isabella, with its "old timber estate house", dark and shiny floors, "wide low-eaved verandas" and "cooling ferns". "Everywhere," he imagines, "the eye would have found pleasure" (32-33). In the fields, labourers "of the olden 
time" work at "undemanding tasks" such as cutting down pods with "gullets, hand shaped knives" like "weapons of medieval knights"; in the "shade", "arcadian figures" stand by the "multicoloured heap of pods" (33-34). Through reverie, Singh fashions a home that is the reverse of his exile, but there is little that is factual about his cocoa plantation. The authors of The Other Side of Paradise provide this description of plantation work reality quite different from Singh's reverie:

But now I no longer knew what I was; ambition became confused, then faded; and I found myself longing for the certainties of my life on the island of Isabella, certainties which I had once dismissed as shipwreck.

Isabella, as much as it is a site of chaos and disorder, is also the site Singh flees to from the greater disorder of London and that London, while offering respite from Isabella, does not allow itself to be read as a space of pure order, as it remains the greater disorder. The text does not offer such simple spaces; rather, it creates spaces riddled with contradiction, so that London can simultaneously be the site of respite from Isabella and the site of the greater disorder. For example, Singh 's descriptions of himself on Isabella, as he at one moment describes himself as unable to obtain "intensity of emotion", only just pages later to describe the "drama and insecurity" of his political group and the ease with which the "emotion" of Isabella could resurface $(38,43,45)$. As it is discussed, displacement is traumatic for Singh.

\section{Trauma and Literature}

In this section, I analyse the impact of trauma on the style of The Mimic Men. Non-linearity, repetition and intertextuality form three important modes of representation in the traumatic narratives in Whitehead's book, all of which are traced in The Mimic Men.

\subsection{Non-linearity}

Cathy Caruth her book, Trauma, Explorations in Memory, questions the form of narrative memory. She suggests the need for a narrative form which does not succumb to closure and coherence, but retains within itself the traces of traumatic disruption and discontinuity. In The Mimic Men, the narrative technique is to quote William Walsh, "dissolving and non-linear, in correspondence with the starts and swerves of the recovering memory, his instrument of self-examination" (62). The novel is divided into three parts. The chronological sequence of events begins with Singh's 's childhood in Isabella, among his family and school friends, and then narrates his move to England, his life in the boarding house run by Lieni, his several sexual adventures, and his eventual marriage to an English girl named Sandra. It then delineates his return to Isabella, where he becomes a successful property developer and building contractor, and his entry into politics with his friend, Browne, and the subsequent rise to power, before giving an account of the break-up of his marriage, his sudden withdrawal from his political career in Isabella to go back to England, his brief liaison with the aristocratic Stella there, and his settling down in the old boarding house (now a hotel) where he starts writing his memoirs. That is the chronological organisation of the events; yet, they follow a disordered sequence. V.S. Naipaul begins the novel in medias res. In Part One, Singh is in London, comparing his impressions of London to those he had shortly after World War II. He questions his political failure, which he sees as the result of the shortcomings of his society. He recounts the story of his university days, his marriage to Sandra, his return to Isabella, and his success in the world of business, politics and the Isabella jet set, followed by the break-up of his marriage. In Part Two, the narrator moves further back in time, to his childhood memories. In Part Three, Singh focuses on his political experiences again and then moves back to the present in London.

\subsection{Intertextuality}

As mentioned above, intertextuality is a key stylistic device of trauma fiction which is used by V.S. Naipaul in The Mimic Men. Whitehead suggests that "the term represents the notion that every text constructs itself as a tissue of quotations, absorbing and transforming material from other texts...Intertextuality is also used in a more specific sense to refer to the particular set of plots, characters, images or conventions which a given text may bring to mind for its readers" (89). In The Mimic Men, there are many things that bring to mind references from external sources. Whitehead writes:

Intertextuality does not necessarily refer to an external source of reference but can operate within a single Corpus or body of work. A writer's fiction can act in dialogue with its own precedents, whether plays, novels, poems or critical essays. In trauma fiction, this can create across an author's work a sense of endless repetition, as if the writing is haunted by an inarticulable force, which can neither be named and confronted nor passed beyond. (93)

In The Mimic Men, like other Naipaul's works, there are many things which bring to mind references from 
Naipaul's personal life. There are also some materials that bring to mind references from Naipaul's other works. Naipaul often reworks and revises in a later text materials and elements he treated in earlier books. To this, Naipaul has remarked, "I feel that at any stage of my literary career it could have been said that the last book contained all the others" ("Two Worlds" 480). Moreover, in The Mimic Men, there are many things that bring to mind references from external sources. John Thieme believes that "The Mimic Men is his most allusive work to date. References to myth, literature and history reverberate throughout the novel; sometimes as a direct part of Singh's narrative and sometimes, rather more indirectly, the prerogative of Naipaul himself' (110).

\section{Conclusion}

As discussed in previous sections, displacement is traumatic for Ralph Singh, the protagonist of The Mimic Men. First, I depicted the Singh's trauma by the illness it caused; PTSD. After demonstrating that displacement is traumatic for Singh, I suggested two ways the narrator responded to his trauma. There are two very broad ways of coming to terms with trauma: "acting out" and "working through". Singh acts out his trauma by his behaviour and reactions in different stages of his life. In childhood, he dreams of India and read books about Aryans, he sees his island as a shipwreck, avoids being among people. He travels to England to find order but he sees greater shipwreck. He starts seeing prostitutes and touring London by train. He eventually marries Sandra, an English girl, for her protection and gets back to Isabella. In Isabella, he enters politics after leaving Sandra. He returns to England after the failure in his political career, resides in a hotel room and starts writing his memoirs. By writing, he starts "working through" his trauma. I also explored the impacts of trauma of displacement on the structural and formal components of The Mimic Men. Thus, non-linearity, repetition and intertextuality formed three important modes of representation of trauma in The Mimic Men.

\section{References}

American Psychiatric Association. (2000). Diagnostic and Statistical Manual of Mental Disorders (4th ed., text rev.). Washington, DC: Author.

Caruth, C. (1995). Trauma: Exploration in Memory. Baltimore: Johns Hopkins University Press.

Dooley, G. M. (2011). The Imaginative Promptings of My Many-Sided Background: V.S. Naipaul's Diasporic Sensibility. In O. P. Dwivedi (Ed.), Literature of the Indian Diaspora (pp. 83-102). New Delhi: Pencraft International.

Herman, J. (1997). Trauma and Recovery: The Aftermath of Violence--from Domestic Abuse to Political Terror. New York: Basic Books.

LaCapra, D. (2004). History in Transit: Experience, Identity, Critical Theory. Ithaca: Cornell UP.

Naipaul, V. S. (1969). The Mimic Men. London: Penguin Books.

Naipaul, V. S. (2001). Nobel Lecture: Two Worlds. Retrieved from http://www.nobelprize.org/nobel_prizes/ literature/laureates/2001/naipaul-lecture-e.html

Rowe-Evans, A. (1997). V.S. Naipaul: A Transition Interview. In F. Jussawalla (Ed.). Conversations with V.S. Naipaul. Jackson: University Press of Mississippi.

Santiago, S. R. (2008). Pessimism and Existentialism in V. S. Naipaul. Journal of Caribbean Literatures, 5(2).

Thiem, J. (1987). The Web of Tradition: Uses of Allusion in V.S. Naipaul's Fiction. Hertford: Hansib Publishing (Caribbean) Ltd.

White, L. (1975). V.S. Naipaul: A Critical Introduction. London: Macmillan Press.

Whitehead, A. (2004). Trauma Fiction. Edinburgh: Edinburgh University Press. http://dx.doi.org/10.3366/ edinburgh/9780748618576.001.0001

Wring History, Writing Trauma. (2001). Baltimore: Johns Hopkins University Press.

\section{Copyrights}

Copyright for this article is retained by the author(s), with first publication rights granted to the journal.

This is an open-access article distributed under the terms and conditions of the Creative Commons Attribution license (http://creativecommons.org/licenses/by/3.0/). 